\title{
Biological test against breast adenocarcinoma cells (MCF-7) of acylated products of 3-methyl-4 thiorhodanine
}

- Lê Hoàng Giàu

- Nguyễn Tô Nhã

- Ngô Thị Thùy Dương

- Tôn Thất Quang

- Nguyễn Kim Phi Phụng

University of Science, VNU-HCM

- Phạm Nguyễn Kim Tuyến

Sai Gon University

\section{- Fritz Duus}

Roskilde University, Denmark

(Received on January $5^{\text {th }} 2015$, accepted on June $22^{\text {th }} 2015$ )

\begin{abstract}
Rhodanine and its derivatives are not only valued for their interesting chemical properties but also present a wide range of bioactivities and their chemical and pharmacological applications have been investigated. From 3-methyl-4-thiorhodanine we synthesized S-acylated and C-acylated

products using (some) carboxylic acid chlorides and the obtained products were studied the anti-proliferative activity by a $S R B$ (sulforhodamine B) assay against a human breast cancer cell line. The results showed that $C$-acylated products are better inhibitors than S-acylated products.
\end{abstract}

Key words: 3-methyl-4-thiorhodanine, 2-thioxo-1,3-thiazolane-4-one, C-acylated, S-acylated, breast cancer cell line (MCF-7).

\section{INTRODUCTION}

Rhodanine derivatives have been proven to be attractive compounds due to their outstanding biological activities and have undergone rapid development as anticonvulsant, antibacterial, antiviral, and antidiabetic agents. At the same time, these have also been reported as Hepatitis $\mathrm{C}$ virus (HCV) protease inhibitors and used as inhibitors of uridine diphospho- $N$ acetylmuramate/L-alanine ligase. Recently, substituted rhodanines were investigated for the aggregation inhibitor properties. Rhodanines are $\underline{\text { classified as nonmutagenic and a long-term study }}$

on the clinical effects of the rhodanine-based Epalrestat as an anti-diabetic, demonstrated that it is well tolerated. Additionally, rhodanines have been designed as inhibitors of various enzymes such as bacterial $\beta$-lactamase and Mur ligases. Rhodanine derivatives were found to have marked mildew-proofing activity. It is interesting to note that the new mildew-proofing agents contain the structure ${ }_{1}-{ }_{0}-$ present in many plant fungicides (tetramethylthiuram disulfide and the salts of dithiocarbamic acid). Due to various possibilities of chemical 
derivatization of the rhodanine ring, rhodaninebased compounds will probably remain a privileged scaffold in drug discovery. Therefore, the synthesis of these compounds is of considerable interest. Recent studies have revealed that 5-benzylidene-3-ethyl rhodanine induced cytotoxicity in a time- and concentration-dependent manner on leukemic cell line, CEM. [1, 2]

Cancer is one of the difficult diseases to be cured, and very few effective drugs are available. The development of novel, efficient, and less toxic anticancer agents remains an important and challenging goal in medicinal chemistry. For specific types of cancer occurring only in women, breast cancer is the second most frequent type of cancer in the world (1.05 million cases) and is by far the most common malignant disease in women ( $22 \%$ of all new cancer cases) [3]. The MCF-7 human breast cancer cell line has been used as an excellent experimental model to improve the efficacy of different therapies before their use in patients [4].

The SRB (sulforhodamine B) method, as originally developed by Skehan et al. [5] is simple, accurate and yields reproducible results. The cells are briefly washed, fixed and stained with this dye (SRB). The incorporated dye is then liberated from the cells in a Tris base solution. An increase or decrease in the number of cells (total biomass) results in a concomitant change in the amount of dye incorporated by the cells in the culture. This indicates the degree of cytotoxicity caused by the test material.

In this paper we report the chemical structures of novel derivatives of 3-methyl-4thiorhodanine which are different in substituents and structures of carbon side chain. Furthermore, in vitro anticancer activity as well as the structure - activity relationships are described. The drastic influence of different substituents and side chains on the inhibition is shown in detail and could contribute to a deeper understanding of the anticancer properties of these interesting classes of compounds.

\section{EXPERIMENTAL}

\section{Chemistry}

The acylation of 3-methyl-4-thiorhodanine (3-methyl-1,3-thiazolane-2,4-dithione) with ten aromatic acid chlorides were performed at two different positions: carbon in position 5 and sulfur in position 4, respectively, to afford two different isomers [6]. By using pyridine as base, pure $S$-acylated products were exclusively obtained for all substituents, on the contrary, with sodium hydroxide as base, the obtained products were pure $C$-acylated ones for all subsituents (see Figure 1). $S$-acylated products of 5 aliphatic acid chlorides (XCOCl where $\mathrm{X}$ is methyl, ethyl, isopropyl, tert-butyl and benzyl) with 3-methyl-4thiorhodanine were also synthesized by the same method. The structures of these compounds were confirmed by their ${ }^{1} \mathrm{H}$ and ${ }^{13} \mathrm{C}$-NMR spectra.

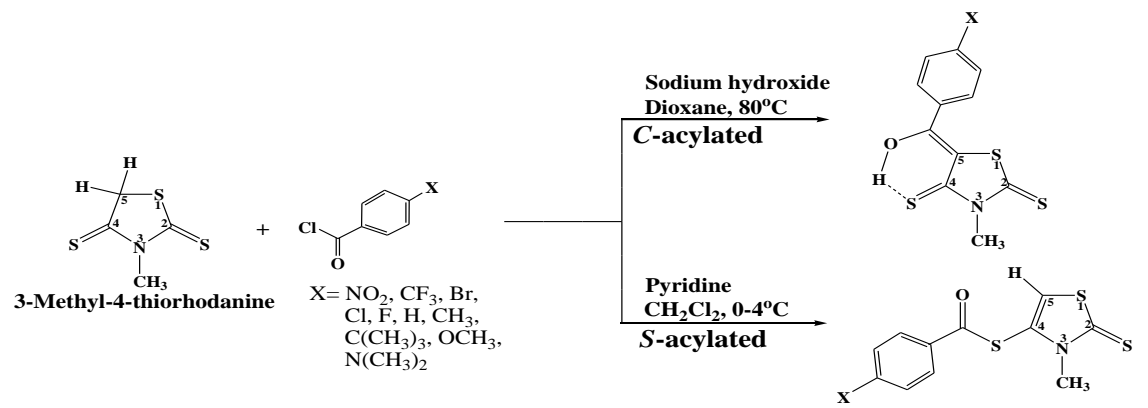

Figure 1. Chemical structures of the $C$ - and $S$ - acylated products of 3-methyl-4-thiorhodanine by ten aromatic carboxylic acid chlorides

\section{Trang 64}




\section{Cytotoxicity}

The cytotoxic activity of the products was screened by using the sulforhodamine $\mathrm{B}$ colorimetric assay method in the MCF-7 cell line. All the assays were done in Molecular Biological Laboratory- Genetic Department-University of Science- VNU-HCMC.

\section{Cell culture}

MCF-7 cells were cultured in E'MEM (Eagle's minimal essential medium) media which was supplemented with $10 \%$ fetal bovine serum and the cells were maintained at $37{ }^{\circ} \mathrm{C}$ in a $5 \%$ $\mathrm{CO}_{2}$ atmosphere with $95 \%$ humidity [7].

\section{Protocol}

All adherent cell lines were detached from the culture flasks by addition of $1 \mathrm{~mL}$ of $0.05 \%$ trypsin-EDTA to make single cell suspensions and viable cells were counted by trypan blue exclusion in a hemacytometer and diluted with medium to give the final concentration. Since the investigated compounds were insoluble in water, they were initially dissolved in DMSO and further diluted with culture medium for analysis. The concentration of DMSO was less than $0.5 \%$ which was found to be non-toxic to the cells. Cells were inoculated at densities 10.000 cells per well and were preincubated for $24 \mathrm{hrs}$ at 37 ${ }^{\circ} \mathrm{C}$ to allow stabilization prior to addition of complexes. Subsequently, the different complexes were incubated for $48 \mathrm{~h}$ in an atmosphere of $5 \% \mathrm{CO}_{2}$ and $95 \%$ relative humidity. The end point of the procedure was determined by the sulforhodamine B (SRB) method, as described below.

Briefly, adherent cell cultures were fixed in situ by adding $50 \mu \mathrm{L}$ of cold $50 \%$ (w/v) trichloroacetic acid (TCA) and incubated during for 60 minutes at $4{ }^{\circ} \mathrm{C}$. The supernatant was then discarded, and the plates were washed five times with deionized water and dried. $100 \mu \mathrm{L}$ of SRB solution $(0.4 \% \mathrm{w} / \mathrm{v}$ in $1 \%$ acetic acid) was added to each well and incubated for $10 \mathrm{~min}$ at room temperature. The plates were air-dried and the bound stain was solubilized with Tris buffer and the optical densities were read on an automated spectrophotometric plate reader at 492 $\mathrm{nm}$ and $620 \mathrm{~nm}$. All of the experiments were carried out at least three times [8].

Plate design

The components in each well of the control is the same as in each well of sample but positive control is camptothecin $0.01 \mu \mathrm{g} / \mathrm{mL}$ replaced for sample, negative control is complete medium, solvent control has no sample, blank control has no cell.

The growth inhibition was determined by using the following equation

where

$O D^{\prime}=O D_{492}-O D_{620}$

$O D=O D_{\text {cell }}^{\prime}-O D_{\text {blank }}^{\prime}$

$O D_{c}: O D$ of $0.25 \%$ DMSO

$O D_{\text {s: }}$ OD of sample 


\section{RESULT AND DISCUSSION}

Table 1. In vitro cytotoxicity of obtained products $(100 \mu \mathrm{g} / \mathrm{mL})$ against MCF-7 cells

\begin{tabular}{|c|c|c|c|}
\hline \multirow{2}{*}{ Structure of samples } & \multirow{2}{*}{$\begin{array}{l}\text { Substituents } \\
\text { (X) }\end{array}$} & \multirow{2}{*}{$\begin{array}{l}\text { Code of } \\
\text { sample }\end{array}$} & $\begin{array}{c}\text { Cell growth } \\
\text { inhibition (I \%) }\end{array}$ \\
\hline & & & Mean $\pm \mathrm{SD}$ \\
\hline \multirow{10}{*}{$\begin{array}{c}\mathrm{CH}_{3} \\
\text { Aromatic } C \text {-acylated } \\
\text { products }\end{array}$} & $\mathrm{NO}_{2}$ & $\mathrm{C} 1$ & $69.18 \pm 3.099$ \\
\hline & $\mathrm{CF}_{3}$ & $\mathrm{C} 2$ & $67.14 \pm 4.923$ \\
\hline & $\mathrm{Br}$ & C3 & $68.22 \pm 4.205$ \\
\hline & $\mathrm{Cl}$ & $\mathrm{C} 4$ & $72.94 \pm 2.407$ \\
\hline & $\mathrm{F}$ & $\mathrm{C} 5$ & $85.31 \pm 2.784$ \\
\hline & $\mathrm{H}$ & C6 & $77.78 \pm 1.700$ \\
\hline & $\mathrm{CH}_{3}$ & $\mathrm{C} 7$ & $71.88 \pm 3.237$ \\
\hline & $\mathrm{C}\left(\mathrm{CH}_{3}\right)_{3}$ & $\mathrm{C} 8$ & $70.61 \pm 1.444$ \\
\hline & $\mathrm{OCH}_{3}$ & C9 & $83.26 \pm 2.138$ \\
\hline & $\mathrm{N}\left(\mathrm{CH}_{3}\right)_{2}$ & $\mathrm{C} 10$ & $28.90 \pm 4.075$ \\
\hline \multirow{10}{*}{$\begin{array}{l}\text { Aromatic } S \text {-acylated } \\
\text { products }\end{array}$} & $\mathrm{NO}_{2}$ & S1 & $19.41 \pm 5.068$ \\
\hline & $\mathrm{CF}_{3}$ & $\mathrm{~S} 2$ & Not determined * \\
\hline & $\mathrm{Br}$ & S3 & $27.83 \pm 5.589$ \\
\hline & $\mathrm{Cl}$ & S4 & $13.82 \pm 3.082$ \\
\hline & $\mathrm{F}$ & S5 & $8.91 \pm 3.025$ \\
\hline & $\mathrm{H}$ & S6 & $5.67 \pm 4.201$ \\
\hline & $\mathrm{CH}_{3}$ & S7 & $6.10 \pm 5.795$ \\
\hline & $\mathrm{C}\left(\mathrm{CH}_{3}\right)_{3}$ & S8 & $12.98 \pm 4.754$ \\
\hline & $\mathrm{OCH}_{3}$ & S9 & $59.73 \pm 2.647$ \\
\hline & $\mathrm{N}\left(\mathrm{CH}_{3}\right)_{2}$ & S10 & $18.38 \pm 2.255$ \\
\hline \multirow{5}{*}{$\begin{array}{c}\text { Aliphatic } S \text {-acylated } \\
\text { products }\end{array}$} & $\mathrm{CH}_{3}$ & S11 & $6.37 \pm 11.298$ \\
\hline & $\mathrm{C}_{2} \mathrm{H}_{5}$ & S12 & $-3.85 \pm 4.713$ \\
\hline & $\mathrm{CH}\left(\mathrm{CH}_{3}\right)_{2}$ & S13 & $0.43 \pm 4.849$ \\
\hline & $\mathrm{C}\left(\mathrm{CH}_{3}\right)_{3}$ & S14 & $-2.82 \pm 7.435$ \\
\hline & $\mathrm{CH}_{2} \mathrm{C}_{6} \mathrm{H}_{5}$ & S15 & $7.70 \pm 5.479$ \\
\hline $\begin{array}{c}\text { Camptothecin } \\
\text { (Positive control) }\end{array}$ & & & $38.60 \pm 2.551$ \\
\hline
\end{tabular}

(*): lack of sample

The cytotoxic activity of the products against the MCF-7 cell line, screened by the SBR assay, expressed as a percentage of cell growth inhibition (I \%), are presented in Table 1.

In general, tested compounds with a percentage of inhibition higher than $50 \%$ may be potential agents for cancer chemoprevention.
In Table 1 , most of the $C$-acylated aromatic products (except the substituent $\mathrm{N}\left(\mathrm{CH}_{3}\right)_{2}$ ) at 100 $\mu \mathrm{g} / \mathrm{ml}$ possess inhibitive percentages higher than $50 \%(67-85 \%)$ indicating a high cytotoxic activity against breast cancer cells.

On the contrary, almost all $S$-acylated aromatic products (except the substituent $\mathrm{OCH}_{3}$ ) did not show any significant cytotoxicity against MCF-7, and especially, the $S$-acylated aliphatic products performed a very weak inhibitive

\section{Trang 66}


ability. The observation showed that the disappearance of benzene ring resulted in a reduction of cytotoxicity.

Among the $S$-acylated products, the one with substituent $\mathrm{OCH}_{3}$ is the most active $(59 \%)$. Besides, the $C$-acylated derivative with substituent $\mathrm{OCH}_{3}$ was also one of the products performing high cytotoxicity $(83 \%)$. The presence of a methoxy group on the benzene ring seems to be necessary to produce high cytotoxicity. That result is also in agreement with the comments in some papers [9].

The presence of the dimethylamino group in both $C$ - and $S$-acylated products induced loss of cytotoxicity (\% I was $28.90 \%$ and $18.38 \%$, respectively).

In summary, $C$-acylated products were always more active than $S$-acylated products.
This result is in agreement with the observation by Matsumoto [10] and some other authors [9] that the presence of a methoxyl group in the molecule has an important role in the cytotoxic ability.

\section{CONCLUSION}

In the acylation reaction of 3-methyl-4thiorhodanine, $C$ - or $S$-acylated products can be obtained depending on the reaction conditions. We found out the best way to obtain either fully $S$-acylated or fully $C$-acylated products. $C$ acylated products showed strong inhibitory ability and may be potent inhibitors of MCF-7 cell proliferation used for cancer chemoprevention. Therefore the relevance of these results needs to be investigated further.

\section{Khảo sát hoạt tính gây độc tế bào ung thư vú (MCF-7) của các dẫn xuất acyl hóa của 3-methyl-4-thiorhodanine}

- Lê Hoàng Giàu

- Nguyễn Tô Nhã

- Ngô Thị Thùy Dương

- Tôn Thất Quang

- Nguyễn Kim Phi Phụng

Trường Đại học Khoa học Tự nhiên, ĐHQG-HCM

- Phạm Nguyễn Kim Tuyến

Đại Học Sài Gòn

- Fritz Duus

Trường Đại học Roskilde, Đan Mạch.

\section{TÓM TÁT}

Phản ứng acyl hóa 3-methyl-4thiorhodanin (2-thioxo-1,3-thiazolan-4-on) bởi các clorur acid có thể xảy ra ở 2 vị trí: C số 5 hay $S$ ở vị trí số 4 để tạo ra sản phẩm là dẫn xuất C-acyl hóa, S-acyl hóa tùy thuộc vào việc sử dụng loại xúc tác base nào.

Trong báo cáo này chúng tôi thử hoạt tính gây độc đối với tế bào ung thư vú (MCF-7) áp dụng trên các dẫn xuất $S$-acyl hóa và $C$ acyl hóa đã tổng hợp được và kết quả cho thấy các dẫn xuất $C$-acyl hóa có hoạt tính 
gây độc tế bào cao hơn các dẫn xuất S-acyl hóa.

Từ khóa: 3-Methyl-4-thiorhodanin, 2-thioxo-1,3-thiazolan-4-on, S-acyl hóa, C-acyl hóa, tế bào ung thư vú, MCF-7.

\section{REFERENCES}

[1]. S. Ravi, K.K. Chiruvella, K. Rajesh, V. Prabhu, S.C. Raghavan, 5-Isopropylidene-3ethyl rhodanine induce growth inhibition followed by apoptosis in leukemia cells, European Journal of Medicinal Chemistry, 45, 2748 (2010).

[2]. B.T. Moorthy, S. Ravi, M. Srivastava, K.K. Chiruvella, H. Hemlal, O. Joy, S.C. Raghavan, Novel rhodanine derivatives induce growth inhibition followed by apoptosis, Bioorganic \& Medicinal Chemistry Letters, 20, 6297 (2010).

[3]. D.M. Parkin, Pathology and genetics of tumors of the breast and female genital organs, Lancet Oncol, 2, 533 (2001).

[4]. S. Matsuo, S. Tanako, J. Yamashita, M. Ogawa, Growth inhibition, $\mathrm{G}_{1}$-arrest, and apoptosis in MCF-7 human breast cancer cells by novel highly lipophilic 5fluorouracil derivatives, Anticancer Res, 12, 1575 (2000).

[5]. P. Skehan, R. Storeng, D. Scudiero, A. Monks, J. McMohan, D. Vistica, J.T. Warren, H. Bokesch S. Kenney, M.R. Boyd, New colorimetric cytotoxic assay for anticancer-drug screening, J. Natl. Cancer Inst, 82, 1107 (1990).
[6]. N.T. Nhã, Synthesis and biological assay against MCF-7 cell line of S-acylated and Cacylated 3-methyl-4-thiorhodanine, Luận văn Thạc sĩ, Bộ môn Hoá Hữu Cơ, Trường ĐH Khoa Học Tự Nhiên, ĐHQG-HCM (2011).

[7]. K.T. Papazisis, G.D. Geromichalos, K.A. Dimitriadis, A.H. Kortsaris, Optimization of the sulforhodamine B colorimetric assay, Journal of Immunological Methods, 208, 151 (1997).

[8]. R. Tammy, L. Bush, E.D. Cross Doersen, E.A. Cashman, S.P. Wright, J.H. Zwolshen, G.F. Davis, D.P. Matthews, D.M. Bender, A.J. Bitonti, Clomiphene analogs with activity in vitro and in vivo against human breast cancer cells, Biochemical Pharmacology, 55, 841 (1998).

[9]. J.C. Le Bail, F. Varnat, J.C. Nicolasb, G. Habrioux, Estrogenic and antiproliferative activities on MCF-7 human breast cancer cells by flavonoids, Cancer Letters 130, 209 (1998).

[10]. K. Matsumoto, Y. Akao, K. Ohguchi, T. Ito, T. Tanaka, M. Iinumad, Y. Nozawaa, Xanthones induce cell-cycle arrest and apoptosis in human colon cancer DLD-1 cells, Bioorganic \& Medicinal Chemistry, 13, 6064 (2005).

\section{Trang 68}




\section{APPENDIX}

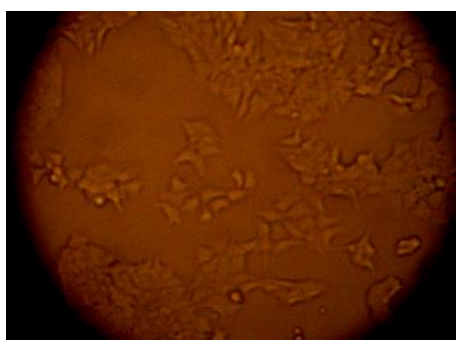

DMSO $0.25 \%$-Negative control $(0.00 \%)$

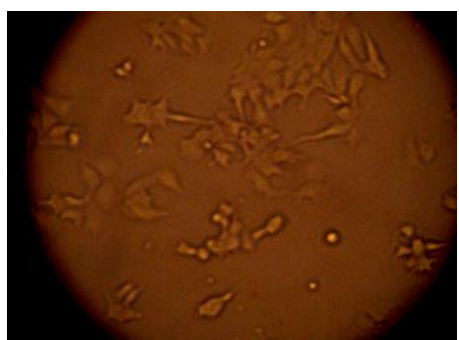

Camptothecin - Positive control (38.60\%)

Appendix 1. Morphological observation of breast cancer cells (MCF-7) of negative and positive control after administration and the percentage of cell growth inhibition

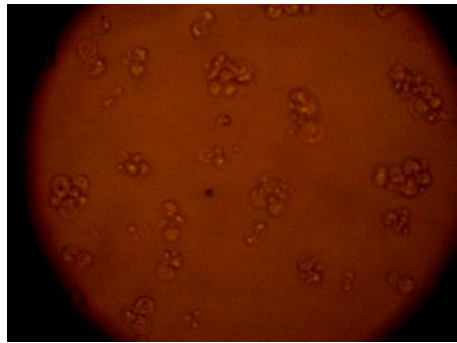

C5 $(85.31 \%)$

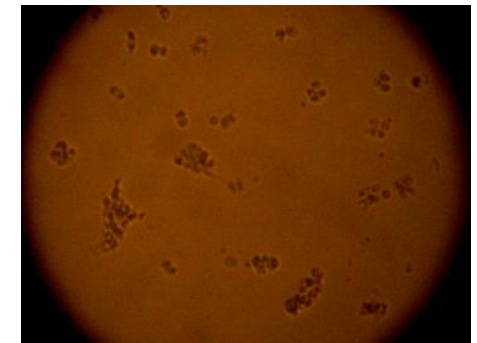

C9 $(83.26 \%)$

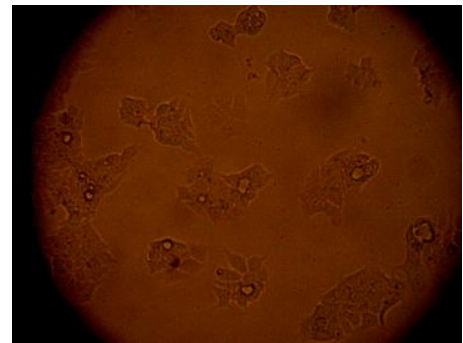

$\mathrm{C} 10(28.90 \%)$

Appendix 2. Morphological observation of breast cancer cells (MCF-7) after administration of some $C$-acylated products and the percentages of cell growth inhibition

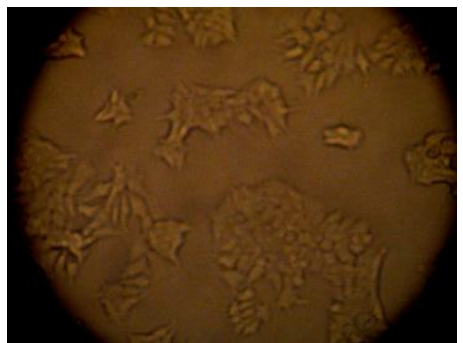

S6 $(5.67 \%)$

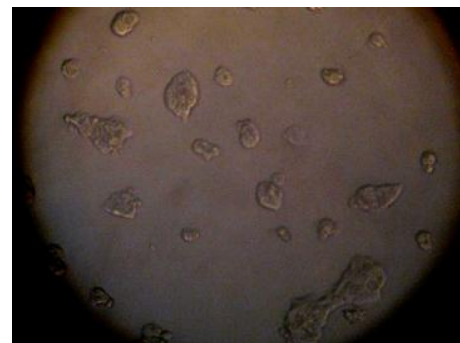

S9 $(59.73 \%)$

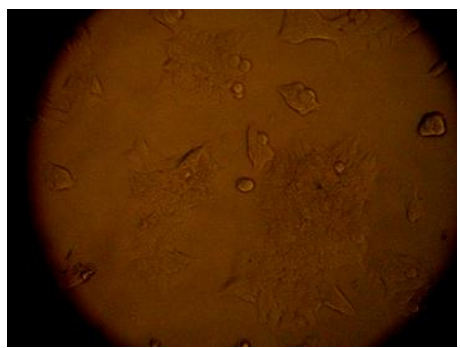

$\mathrm{S} 12(-3.85 \%)$

Appendix 3. Morphological observation of breast cancer cells (MCF-7) after administration of some $S$-acylated products and the percentages of cell growth inhibition 